dzisiaj: zauważył że wzbogacił się warsztat pracy nauczyciela (mnogość podręczników i materiałów pomocniczych wyzwala postulat zwiększenia progu wymagań), konieczne jest podjecie zabiegów dla wzmocnienia rangi historii w ramach kształcenia ogólnego, uzasadnione wydaje się zorganizowanie konferencji z udziałem dydaktyków, historyków, nauczycieli historii w œlu wypracowania wspólnej płaszczyzny porozumienia;

jutra: powinniśmy mieć świadomość, iż nasz uczeń zmienia się wraz z przeobrażeniami cywilizacyjnymi - gwarant skuteczności działań nauczyciela oraz świadomość, że nauczyciel powinien być rzetelnym historykiem nowej formacji intelektualnej.

Zapowiedż kolejnego spotkania dydaktyków w czerwcu 1996 roku w Olsztynie przyjęta została z dużym zadowoleniem. Nadmienić należy, że w pierwszym dniu konferencji odbyła się promocja podręcznika historii do klasy IV-tej szkoły podstawowej, pióra prof. dr J. Topolskiego. Od tej chwili nauczający dziejów na szczeblu propedeutycznym dysponuje alternatywnym podreccznikiem Zainteresowanych szczegółowymi treściami zapraszamy do lektury książki „Nauczyciel historii. Ku nowej formacji dydaktycznej” pod red. M. Kujawskiej, która w najbliższych dniach ukaże się na rynku czytelniczym.

\title{
Ogólnopolski Zjazd Pedagogiczny. Toruń 31.08.-2.09. 1995 r.
}

Pod ogólnym hasłem demokracja i wychowanie odbyl się wł dniach II Ogólnopolski Zjazd Pedagogiczny ${ }^{1}$, zorganizowany przez Polskie Towarzystwo Pedagogiczne. Gościny obradom Zjazdu udzielił wspaniały ośrodek bielański Uniwersytetu im. Mikołaja Kopernika w Toruniu, campus podobny w swej formie m.in. do uniwersyteckiego centrum w Oslo-Blindern.

W ten sposób Polskie Towarzystwo Pedagogiczne, którego poprzednikiem było Poznańskie Towarzystwo Pedagogiczne ${ }^{2}$, przejęło tradycje inicjatywy Związku Nauczycielstwa Polskiego, który w poprzednich okresach historycznych był organizatorem zjazdów pedagogicznych w przelomowych fazach rozwoju politycznego Polski i meandrów oświaty, szkolnictwa i nauk o wychowaniu ${ }^{3}$, obecnie zaś zatracil swą aktywność w tej dziedzinie.

Przebieg Zjazdu pomyślany był wielowarstwowo i obejmował obrady plenarne oraz różne formy pracy grupowej. Obrady plenarne obejmowały referaty indywidualne oraz $\mathrm{tw}$. wielogłosy z udziałem zaproszonych specjalistów. $\mathrm{Na}$ prace grupowe skladały się spotkania naukowe w sekcjach problemowych oraz sympozja.

Pierwszym z wystąpień plenarnych było przemówienie programowe przewodniczącego Zarzqdu Głównego PTP prof. dr hab. Zbigniewa Kwiecińskiego pt. Edukacja wobec wyzwań demokracji. Określił w nim m.in. cele i zadania Zjazdu, który spodziewa się „....oceny stanu, trendów rozwojowych, perspektyw i problemów pedagogiki polskiej”, uzyskania stanowiska „MEN w sprawie stanu i perspektyw reformy oświaty"4. W przemówieniu postawiono szereg pytań, które mogłyby pobudzić do gruntownej refleksji zarówno teoretyków nauk o wychowaniu, jak

' J. Hellwig Ogolnopolaki Zjazd Pedagogicrny Pnlvtega Thwarrystwa Pedagnglcznego. Wanzawa-Rembertáw, .Nauka Polska" 1993, nit 4, a $115-117$.

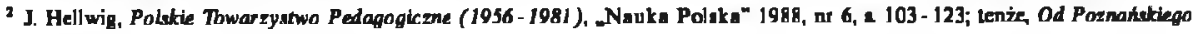
Towarzystwa Pedagogiczneqa do Oddziah Polutiega Tbwarzystwo Pedagogicznego (1956-1981), Prablemy Rozwoju Edukachl Biuletyn PTP, Pomań 1989 nr 1, a 6 - 29.

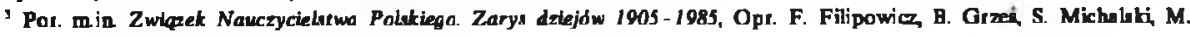
Walergk, Watep J. Hellwig, Warnzawa 1986 paseim.

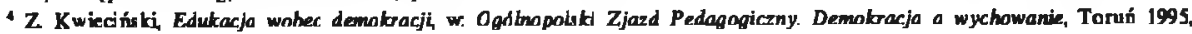
e 10 . 
i praktyków, a także, może w szczególności, decydentów, polityków nad stanem polskiej oświaty, szeroko rozumianych problemów wychowawczych oraz teorii i aplikacji nauk pedagogicznych. Spośród plejady pytań wymieńmy przykładowo kilka: „Czy sami mamy już jasność, jak rozwijać system oświaty? Co zrobiono po 1989 roku, czego nie zrobiono, co zepsuto, co jest do zrobienia? Co myśla o tym aktualni i byli ministrowie, eksperci i nauczyciele? $\mathrm{Czy}$ i na ile rozbudzone sq inicjatywy środowisk lokalnych w budowaniu swoich systemów oświatowych? Czy my musimy powtórzyć błedy Zachodu?..."

„Czy i jak prace naukowe pedagogów spełniają kryteria naukowości? Czy angażujemy się jako środowisko na rzecz rozwoju dzieci i rozwoju kraju? Czy potrafiliśmy budować teorię wskroś podzialów dyscyplinarnych, korzystać z psychologii, socjologii i filozoffi? Czy i jak odradzaja sie dyscypliny innych nauk wspomagajace pedagogikę? Jakie wyzwania epistemologiczne $\mathrm{i}$ aksjologiczne niosq polskie i nie tylko polskie przemiany? Czy dalej beda obowiązywać wzory uprawiania pedagogiki zdrowo-rozsq̨dkowej i jako stosowanych uogólnień z przodującej praktyki, czy pedagogiki hermeneutyczno-krytycznej i krytycznie zaangażowanej?'s'.

W drugim dniu przewodniczący Komitetu Nauk Pedagogicznych PAN prof. dr hab. Tadeusz Lewowicki omówił stan i perspektywy nauk pedagogicznych.

W trzecim dniu obrad plenarnych sekretarz stanu w MEN przedstawił stan i perspektywy reformy oświaty.

W toku obrad plenarnych w pierwszym i drugim dniu miały miejsce wystapienia w formie wielogłosów. Na temat „Tradycje demokratycznej myśli w pedagogice polskiej a wyzwania współczesne" wypowiadali się prof. prof. Stefan Wołoszyn, Mikołaj Kozakiewicz i ks. Janusz Tarnowski. I znów nawiązywano interesująco do naszych skarbów przeszłości wywodząc geneze i rozwój ideii demokratycznych w polskiej pedagogice.

W drugim dniu w wielogłosie plenarnym nt Nurty myślenia we współczesnej pedagogice wzięli udział profesorowie: Joanna Rutkowiak, Roman Schulz, dr hab. Bogusław Sliwerski oraz ks. dr Marian Nowak.

W trzecim dniu odbyła się interesująca dyskusja byłych wiceministrów edukacji narodowej i eksportów MEN. Można było porównać różne wizje stanu i perspektyw polskiej oświaty w kontekście restrykcji finansowych cofających naszą oświatę wstecz i powodujących fakt, iż może w innych dziedzinach życia „zbliżać się będziemy do Europy", to w dziedzinie edukacji, a w konsekwencji w funkcjonowaniu człowieka w nowych warunkach, przewidywać należy znaczny regres. Istnieje powszechny brak zrozumienia u rządzących, iż oświata stanowi wspaniał̧̨ przynosz̨̨ca określone korzyści inwestycję.

W grupach roboczych i podczas sympozjów problemowych przedstawiono ponad 250 referatów.

Można przyjąć, że przy takiej organizacji obrad udało się wszechstronnie naświetlić węzłowe problemy oświatowe stojące wobec zagrożeń czasów współczesnych $i$ wyprowadzić ich genezę. Były jednak wypadki przypadkowego przydziału uczestników do zespołów nie w pełni odpowiadających ich specjalnościom naukowym.

Zjazd podjał niewątpliwie ważkie dla polskiej oświaty i nauk pedagogicznych problemy. Uczestnicy zjazdu w swoich wystapieniach zajmowali stanowisko wobec niepokojacych problemów, jakie zaszły w ostatnich czasach, a m.in. upadek instytucji wychowania przedszkolnego, nie zawsze korzystne dla demokracji skutki lawinowego rozwoju prywatnych instytucji wychowawczych i edukacyjnych wszystkich szczebli; problemy przekwalifikowywania pracowników, zagadnienia szkolnictwa zawodowego $i$ jego dostosowywania się do zmieniających się warunków pracy zawodowej; wiele zazębiających się kwestii związanych z organizacja pracy wewnątrzszkolnej i realizacja programów nauczania; sprawy wykształcenia kobiet; problemy pomocy w edukacji polskiej Polakom na Wschodzie $\mathrm{i}$ ew. repatriantom itp.

I Ibidern, \& 11 i 12. 
Organizatorzy opublikowali abstrakty referatów. Dużą korzyść może przynieść pełne wydanie materiałów Zjazdu. Mogłyby one być ważnymi wskazaniami normatywno-praktycznymi dla decydentów rozwoju polskiego szkolnictwa i nauk o wychowaniu. Czy będą? Pokaże czas.

Podczas obrad liczne oficyny wydawnicze wystawiły wydane publikacje. Wystawom towarzyszył kiermasz książek.

Jan Hellwig

\section{Z historii ksztalcenia nauczycieli w Krośnie 1895 - 1995}

W dniach 19 -20 października 1995 r. w Urzędzie Wojewódzkim w Krośnie odbyła się sesja naukowa poświęcona 100-letniej historii zakładów kształcących nauczycieli; organizatorzy, Kuratorium Oświaty i Kolegium Nauczycielskie w Krośnie zaprosili do udziału w konferencji historyków wychowania, przedstawicieli nauk pedagogicznych i filozoficzno-społecznych z Warszawy, Krakowa, Rzeszowa oraz grono pedagogów z Krosna. Konferencja zgromadziła nauczycieli i wychowanków byłych szkół pedagogicznych funkcjonujących w Krośnie w latach 1895-1995.

W czasie konferencji z referatami wystapily następujące osoby: prof. dr hab. Andrzej Meissner - Powstanie i działalność Państwowego Seminarium Nauczycielskiego Męskiego w Krośnie w latach 1895-1937, prof. dr hab. Zbigniew Krawczyk - Model prognostyczny ksztalcenia nauczycieli, prof. dr hab. Jacek Chrobaczyński - Tajne nauczanie na Podkarpaciu, dr Kazimierz Szmyd - Analiza dziejów Liceum Pedagogicznego w latach 1937 -1961, mgr Adam Krzanowski - Kształcenie nauczycieli w szkołach pedagogicznych w Krośnie w latach 1960-1991, mgr Henryk Olbrycht - Funkcjonowanie Państwowego Studium Kulturalno-Oświatowego i Bibliotekarskiego w okresie 1971-1995, mgr Franciszek Tereszkiewicz i mgr Krzysztof Kasprzyk - Działalność Kolegium Nauczycielskiego Języka Angielskiego i Filologii Polskiej.

W drugiej części konferencji interesujące referaty przedstawili: prof. dr hab. Anna Lukawska

- Kształcenie wstępne w procesie stawania się nauczycielem, prof. dr hab. Józef Lipiec - Filozoficzne podstawy wychowania, prof. dr hab. Jan Szmyd - Podstawowe antynomie zawodu nauczycielskiego a zagadnienie doboru kandydatów na studia pedagogiczne, dr Krzysztof Polak - Indywidualne teorie nauczycieli, dr Stanisław Bortnowski - Jak kształcić polonistów?, dr Teresa Wojtasińska - Nauczyciel w oczach młodzieży szkół podstawowych - oczekiwania i rzeczywistość, dr Wanda Terlecka - Specyfika kształcenia pedagogicznego czynnych zawodowo nauczycieli - refleksje nauczyciela akademickiego, dr Jadwiga Kędzierska - Zadania zawodowe nauczycieli a koncepcja treści ich kształcenia, dr Danuta Skulicz - Konstruowanie programów poszerzających przez nauczycieli - studentów pedagogiki wczesnoszkolnej, dr Maria Koś - Rola praktyk pedagogicznych w przygotowaniu zawodowym nauczycieli.

Konferencja nakreśliła historię szkół pedagogicznych w Krośnie. Wskazano na bogate tradycje kształcenia nauczycieli $\mathrm{i}$ ich znaczenie w ożywieniu środowiska oświatowo-kulturalnego wsi galicyjskiej. Pedagodzy i naukowcy wskazali na systemy kształcenia nauczycieli, dokonali prognozy rozwoju nowych form kształcenia nauczycieli, jak i funkcjonowania systemu wartości, które decydują o podejmowaniu ksztalcenia i zdobywaniu zawodu nauczyciela. Kurator Oświaty mgr Marian Duda wskazał na istotne obszary kształcenia nauczycieli dla potrzeb woj. krośnieńskiego. Pytanie - jakiego nauczyciela wspólcześnie nam potrzeba, kim ma być nauczyciel? spotkało się z szerokim rezonansem.

Pracownicy nauki podjęli próbę nakreślenia sylwetki nauczyciela jako osoby wykształconej i refleksyjnej, sprawnej intelektualnie oraz posiadającej niezbędne techniczne dyspozycje wzbogacające wiadomości i umiejętności. Zasadniczą wartością nauczyciela powinno być jego dążenie do ksztaltowania osobowości wychowanka, zdobywania wiedzy i jej spożytkowania w pracy dla 